\title{
DISAPPEARANCE FROM SERUM OF I'131-LABELED L-THYROXINE AND L-TRIIODOTHYRONINE IN EUTHYROID SUBJECTS ${ }^{1}$
}

\author{
By KENNETH STERLING, ${ }^{2}$ JOYCE COHEN LASHOF, ${ }^{3}$ AND EVELYN B. MAN \\ (From the Department of Internal Medicine, Yale University School of Medicine, \\ New Haven, Conn.)
}

(Submitted for publication February 10, 1954; accepted March 22, 1954)

The present report describes disappearance curves of $I^{181}$-labeled 1-thyroxine and 1-triiodothyronine. The radioactive compounds were injected intravenously in eleven euthyroid subjects, and the radioactivity of the serum was determined daily for ten to fourteen days.

\section{MATERIALS AND METHODS}

Eleven clinically euthyroid subjects were selected: two medical student volunteers, six patients with neurological disorders hospitalized for rehabilitation, one with chronic glomerulonephritis, one convalescing from a myocardial infarction, and one psychoneurotic patient without detectable organic disease. The serum butanol extractable iodines (BEI) of nine of the eleven subjects were within the normal range (1).

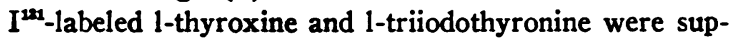
plied by Abbott Laboratories. Upon receipt, the triiodothyronine was purified of five per cent of contaminating thyroxine by paper chromatography with a butanoldioxane-ammonia solvent (2) controlled by radioautography. The lots of radiothyroxine were also chromatographed but impurities were not removed.

Patients R. W., I. T., F. M., and R. K., received fifteen drops of Lugol's solution daily, while patients $\mathbf{M}$. A., V. F., M. H., E. K., and O. C. and the normal volunteers were given three drops of saturated potassium iodide solution daily for two or more days prior to and throughout the course of the studies. Venous blood samples were taken ten minutes after intravenous injection of 25 to $50 \mu \mathrm{c}$. of the radioactive compounds (containing 1 to 6 micrograms of iodine) and then daily for ten to fourteen days. Duplicate $1 \mathrm{cc}$. aliquots of serum were dried in aluminum planchets with $0.1 \mathrm{cc}$. of one per cent detergent solution (Hemosol) to minimize cracking and flaking of the dried films.

Radioactive assay was done in a windowless flow proportional counter similar to the model designed by Robin-

1 This work was supported by Contract No. DA-49007-MD-116 issued by the Medical Research and Development Board, Office of the Surgeon General, United States Army.

2 This work was done in part during the tenure of a Postdoctoral Fellowship of the National Foundation for Infantile Paralysis.

8 Postdoctoral Fellow of the National Foundation for Infantile Paralysis. son (3). Corrections for radioactive decay were made when necessary. Usually all samples from each patient were counted within a few hours after the end of the study.

\section{RESULTS AND INTERPRETATIONS}

The injection of radiothyroxine was followed in all instances by a relatively rapid initial fall in radioactivity of the serum (Figure 1 ). This was attributed to a distribution phase (or phases) and was not subjected to further analysis. After two days the serum radioactivity declined more gradually, forming a straight line when plotted semilogarithmically. This slow exponential component of the disappearance curve was interpreted as the rate of degradation of the administered radiothyroxine or replacement of tagged by untagged thyroxine, hence a measure of the turnover rate of the hormone.

From the linear component of the disappearance curve extrapolated back to zero time (Figure 1) the half-time of thyroxine turnover was obtained graphically. The turnover rate was computed from the half-time. ${ }^{4}$ These calculations depend

- Calculation of Thyroxine Turnover Data (Subject M. A., Figure 1)

Half-time $\left(t_{1 / 2}\right)=5.9$ days (obtained graphically from of thyroxine linear semilogarithmic plot. Figure 1). disappearance.

Turnover rate $\begin{aligned}(k \times 100)=\frac{100 \times \ln 2}{t_{1 / 2}} & =\frac{100 \times 0.693}{5.9 \text { days }} \\ & =11.7 \% / \text { day }\end{aligned}$

expressed as \%/day.$$
=11.7 \% / \text { day }
$$

This represents the per

cent of body's extrathy-

roidal thyroxine pool.

These relations may be derived from the equation for the exponential decay:

$$
A=A_{0} e^{-k t}
$$

where

$A=$ Radiothyroxine at any time

$A_{0}=$ Radiothyroxine at zero time

$\mathbf{t}=$ Time in days

$\mathbf{k}=$ Turnover rate as fraction of the body's extrathyroidal thyroxine pool turned over per day. This is conveniently expressed as per cent per day $(k \times 100)$. 
upon the assumption that a steady state existed; which appears reasonable in the absence of significant alterations in the clinical condition.

The kinetic data from thyroxine and triiodothyronine disappearance curves are listed in Table I. Triiodothyronine curves had a shorter half-time and faster rate of disappearance (Figure 1) than thyroxine. Because of the small groups of patients, it is of interest to compare the successive studies with 1-thyroxine and 1-triiodothyronine performed seven weeks apart in subject $R$. $K$. The more rapid disappearance rate of triiodothyronine is clearly evident (Figure 2).

The "extrathyroidal thyroxine iodine pool" in micrograms was estimated from the quotient, total radioactivity injected

radioactivity per microgram of $\mathrm{BEI}$; the denominator was obtained from the zero time extrapolation which was taken to represent radioactivity in serum if distribution had occurred instantaneously after injection. In the two normal volunteers the pools approximated 350 micrograms of extrathyroidal thyroxine iodine ( 340 and 356 micrograms in W. J. and E. S., respectively). The product of these pools and the turnover rates (Table I) gave values approximating 40 micrograms of thyroxine iodine secreted and degraded daily.

The estimated pools in the nine hospitalized patients were variable; different lots of radiothyroxine gave different values, possibly owing to variable amounts of non-thyroxine radioactive organic compounds demonstrated by chromatography. Such radioactive contaminants would raise the numerator of the above quotient, but if rapidly degraded or excreted, they would not affect

Data from disappearance curves of $I^{131}$-labeled thyroxine and triiodothyronine in euthyroid subjects

\begin{tabular}{|c|c|c|c|c|c|c|c|}
\hline \multirow[b]{2}{*}{$\begin{array}{l}\text { Compound } \\
\text { administered }\end{array}$} & \multirow[b]{2}{*}{$\begin{array}{l}\text { Patient } \\
\text { and } \\
\text { unit No. }\end{array}$} & \multirow[b]{2}{*}{ Age } & \multirow[b]{2}{*}{ Sex } & \multirow[b]{2}{*}{ Diagnosis } & \multirow[b]{2}{*}{$\begin{array}{c}\text { BEI } \\
\text { micro- } \\
\text { grams } \\
\text { (normal } \\
3.2-6.4)\end{array}$} & \multicolumn{2}{|c|}{ Kinetic data } \\
\hline & & & & & & $\begin{array}{l}\text { Half- } \\
\text { time } \\
\text { th/2 } \\
(d a y s)\end{array}$ & $\begin{array}{c}\text { Turnover } \\
\text { rate } \\
\mathbf{k} \mathbf{X}^{100} \\
\left.(\%\rangle_{d a y}\right)\end{array}$ \\
\hline \multirow{9}{*}{$\begin{array}{l}\text { In-tagged } \\
\text { l-thyroxine }\end{array}$} & W. J. & 24 & $\mathbf{M}$ & Normal volunteer & 4.3 & 6.4 & 10.8 \\
\hline & E. S. & 24 & $\mathbf{M}$ & Normal volunteer & 4.1 & 5.6 & 12.4 \\
\hline & $\begin{array}{l}\text { R. W. } \\
\text { 39-03-33 }\end{array}$ & 30 & $\mathbf{M}$ & $\begin{array}{l}\text { Traumatic myelopathy } \\
\text { Paraplegia }\end{array}$ & 5.0 & 7.5 & 9.3 \\
\hline & I. T. & 53 & F & Hemiplegia & 5.9 & 9.5 & 7.3 \\
\hline & $\begin{array}{l}\text { M. A. } \\
\text { 38-69-88 }\end{array}$ & 60 & $\mathbf{F}$ & Hemiplegia & 6.7 & 5.9 & 11.7 \\
\hline & $\begin{array}{l}\text { V.F. } \\
\text { B48561 }\end{array}$ & 35 & F & $\begin{array}{l}\text { Congenital myelopathy } \\
\text { Paraplegia }\end{array}$ & 6.0 & 5.2 & 13.3 \\
\hline & $\begin{array}{l}\text { F. M. } \\
39-00-80\end{array}$ & 63 & F & Hemiplegia & 3.9 & 6.0 & 11.5 \\
\hline & R. K. & 46 & $\mathbf{M}$ & $\begin{array}{l}\text { Traumatic myelopathy } \\
\text { Paraplegia }\end{array}$ & 4.5 & 6.1 & 11.4 \\
\hline & & & & Mean & & 6.5 & 11.0 \\
\hline \multirow{5}{*}{$\begin{array}{l}\text { I'1n_tagged } \\
\text { l-triiodo- } \\
\text { thyronine }\end{array}$} & $\underset{37-77-77}{\text { R. }}$ & 46 & $\mathbf{M}$ & $\begin{array}{l}\text { Traumatic myelopathy } \\
\text { Paraplegia }\end{array}$ & 5.2 & 2.4 & 28.9 \\
\hline & $\underset{38-35-10}{\text { M. H. }}$ & 68 & $\mathbf{M}$ & Myocardial infarction & 4.4 & 2.2 & 31.5 \\
\hline & $\begin{array}{l}\text { E. K. } \\
39-29-24\end{array}$ & 43 & $\mathbf{F}$ & Psychoneurosis & 一* & 2.5 & 27.7 \\
\hline & $\begin{array}{l}\text { O. C. } \\
39-03-90\end{array}$ & 46 & $\mathbf{M}$ & $\begin{array}{l}\text { Chronic glomerulo- } \\
\text { nephritis }\end{array}$ & 一* & 3.2 & 21.6 \\
\hline & & & & Mean & & 2.6 & 27.4 \\
\hline
\end{tabular}

* Not determined because of previous intravenous pyelography. 
I ${ }^{181}$-THYROXINE AND TRIODOTHYRONINE DISAPPEARANCE CURVES

DISAPPEARANCE CURVES OF SERUM RADIOACTIVITY
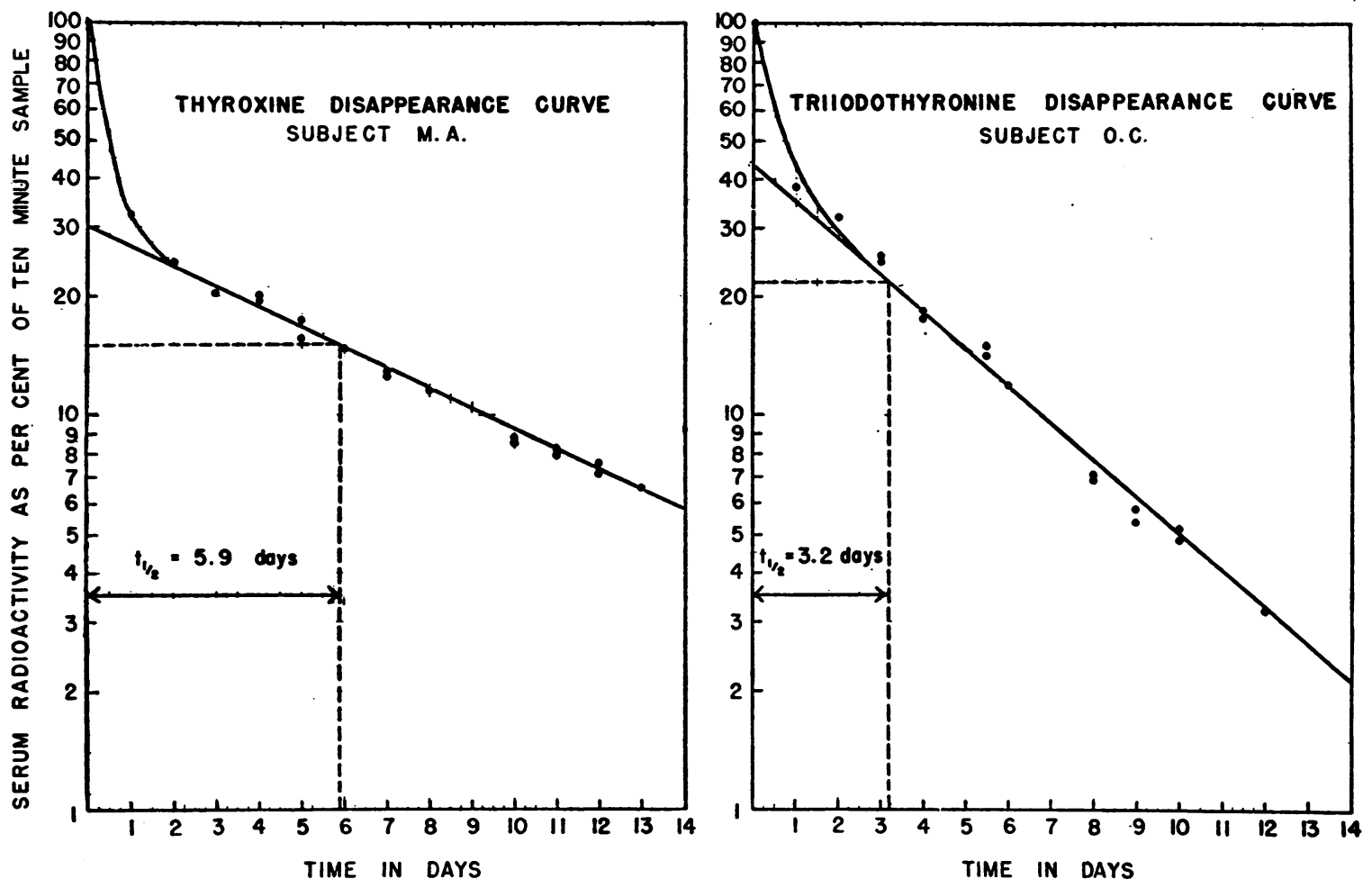

Fig. 1. Plot of Serux Radioactivity

(Logarithmic Scale) agannst Thas

DISAPPEARANCE CURVES OF SERUM RADIOACTIVITY

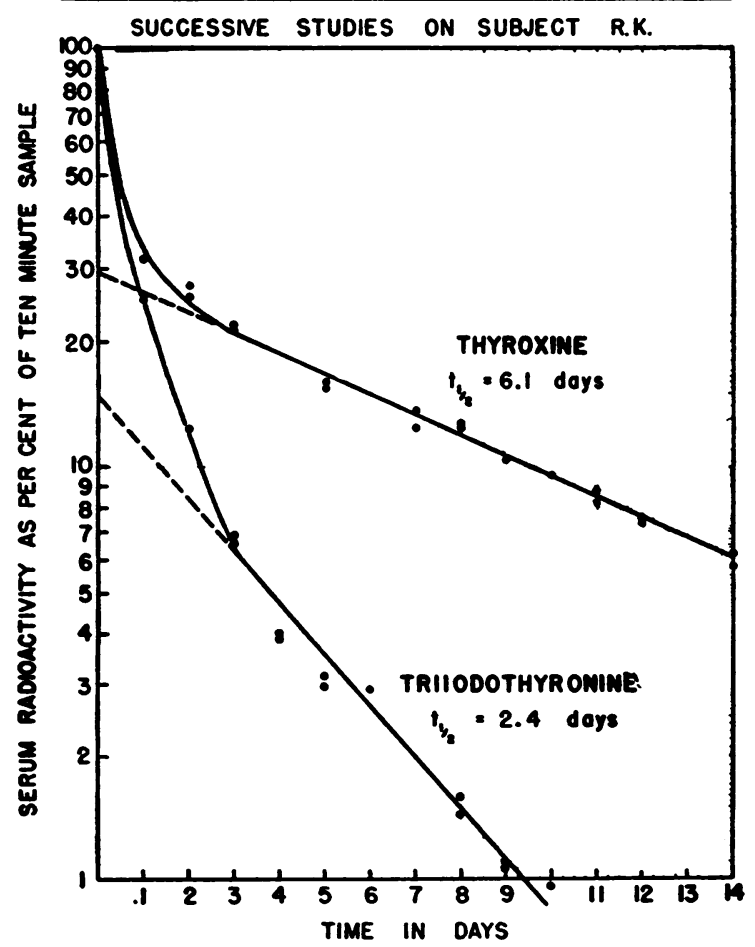

Fig. 2. Plot of Serum Radionctivity (Logarithmic SCALE) Against Time the denominator, thus yielding an overestimation of the pool. The slow component of disappearance should not be significantly affected. The studies with the normal volunteers were obtained with a lot of radiothyroxine purified by column chromatography (Abbott Laboratories) and checked on receipt for absence of contaminants by paper chromatography.

\section{DISCUSSION}

The "extrathyroidal thyroxine pool" is thought to represent a first approximation of the proteinbound thyroxine mainly in the extracellular fluid compartment including the plasma. It is recognized that there may be an inherent error due to inequalities of rates of thyroxine degradation in different sites. For example, the liver may remove an excessive proportion of radiothyroxine from the plasma prior to distribution in extravascular thyroxine stores, and this may depress the zero time extrapolation value. This error is probably small and may be corrected in future studies by data on excretion of the radioactive label.

The distribution of various radioactive thyroxine preparations after intravenous injection has 
been the subject of previous work $(4,5)$. In the present report no attempt has been made to analyze the distribution of administered labeled hormone into various body compartments or sites. The data are recorded simply as disappearance curves which exhibit a slow component after distribution is complete. The semilogarithmic plot of this slow component formed a straight line throughout the study which lasted more than twice the biologic half-life. The prior administration of non-radioactive iodine was intended to minimize thyroid uptake and reutilization of radioiodine liberated on degradation of the administered labeled hormone. By simple dilution effect, the presence of larger amounts of the non-radioactive form of the element may be expected to diminish the absolute amount of radioactive iodine taken up by the euthyroid gland without necessarily influencing the output of hormone $(6-8)$. Under these conditions, the disappearance curve should reflect peripheral degradation of labeled material and its replacement by newly synthesized unlabeled hormone. The turnover rates computed should be equal to the rates of formation and degradation, which in a steady state are identical. The injection of tracer amounts of labeled material (containing 1 to 6 micrograms of iodine) would not be expected to have an appreciable effect upon the subject's physiologic state or the amount of circulating thyroid hormone.

The validity of the turnover data depends upon the further assumption that the administered $\mathrm{I}^{181}$ tagged 1-thyroxine behaves in vivo in precisely the same fashion as the natural hormone secreted by the thyroid gland. Gordon, Gross, O'Connor, and Pitt-Rivers (9) have shown that radiothyroxine added to plasma in vitro is indistinguishable electrophoretically from the naturally occurring thyroxine-alpha-globulin complex. On the other hand, the data of Myant and Pochin (5) suggest possibly significant differences in the distribution phase which warrant further study. These authors suggested that the 80 microgram doses of thyroxine may have represented an excessive addition to the circulating hormone.

Biosynthesized hormone was employed in the recent paper of Hamolsky, Freedberg, Kurland, and Wolsky (10) which reported data on the disappearance of radioactivity in euthyroid, thyrotoxic and myxedematous subjects after intravenous infusion of plasma obtained from thyrotoxic patients two to six days after $I^{181}$ therapy. The mean half-time in four euthyroid individuals was 55.7 hours (2.3 days), a much shorter half-time than the present mean of 6.7 days. Unfortunately, their observations were not extended beyond 70 hours. As they suggest, a more prolonged study might have revealed a slower component than they used in their computations. This could well account for the discrepancy. Inspection of the disappearance curves of the present report show that if no points had been obtained after the third day, it would not have been possible to plot the slow linear component which has been followed for more than two half-lives in the present data. A study in progress by Berson and Yalow using biosynthesized hormone but with observations over a twoweek period (11) has thus far yielded results in general agreement with the present findings.

Since Gross and Pitt-Rivers identified triiodothyronine in human plasma $(12,13)$, this compound has been shown to have a potent calorigenic effect in myxedematous subjects (14). In view of the observations that it exerts its calorigenic effect more rapidly but for a briefer period than thyroxine (15-17), the more rapid disappearance of labeled triiodothyronine reported here is not unexpected. A comparison of disappearance curves of $\mathrm{I}^{181}$-tagged thyroxine and triiodothyronine has been reported (15) in a single treated myxedematous patient with findings similar to the present results in euthyroid subjects. On the basis of such data and other evidence $(18,19)$ it has been suggested that while thyroxine bound to serum protein (alpha-globulin) (9) is the principal form of circulating thyroid hormone, triiodothyronine may be the active principle which enters the tissue cells, and may be formed by peripheral deiodination of thyroxine.

No attempt has been made to estimate a "pool" of triiodothyronine in the absence of more definite knowledge of its concentration and its significance in the serum. The concentration of triiodothyronine in plasma is unknown, but is probably minute $(13,19)$. Its biologic decay may not be strictly comparable to the turnover rate of a predominantly extracellular component such as circulating thyroxine. Triiodothyronine has been shown to be less firmly bound to serum protein than thyroxine $(19,20)$. This may account for the more rapid 
disappearance from the serum. The triiodothyronine disappearance curves and the "turnover rates" derived must therefore be viewed as empirical data pending further clarification of the role of this compound in the metabolism of the thyroid hormone.

\section{SUMMARY}

1. Tracer amounts of 1-thyroxine or 1-triiodothyronine labeled with $\mathrm{I}^{\mathbf{1 3 1}}$ were injected intravenously in euthyroid subjects.

2. The subjects received non-radioactive iodine during the studies to minimize thyroid uptake and reutilization of radioiodine liberated on degradation of the administered compounds.

3. Serum radioactivity was measured on blood samples drawn ten minutes after injection, and daily for two weeks.

4. There was a rapid initial fall, which was attributed to distribution of the compound. Within two days after injection of radiothyroxine, the serum radioactivity declined more gradually, forming a straight line when plotted semilogarithmically. This slow exponential component of the disappearance curve was interpreted as indicating thyroxine turnover, or the rates of formation and degradation, which in a steady state should be identical. The mean half-time of thyroxine turnover in six subjects was 6.7 days.

5. The disappearance curve observed after injection of labeled triiodothyronine was much more rapid, with a mean half-time of 2.7 days in four subjects. Successive studies with 1-thyroxine and 1-triiodothyronine in one individual clearly demonstrated the more rapid disappearance of the latter compound.

6. The interpretation of triiodothyronine disappearance curves must await further knowledge of its concentration in the serum and its precise role in the metabolism of the thyroid hormone.

\section{REFERENCES}

1. Man, E. B., Kydd, D. M., and Peters, J. P., Butanolextractable iodine of serum. J. Clin. Invest., 1951, 30, 531.

2. Gross, J., and Leblond, C. P., The presence of free iodinated compounds in the thyroid and their passage into the circulation. Endocrinol., 1951, 48, 714.
3. Robinson, C. V., Windowless, flow type, proportional counter for counting $C^{24}$. Science, 1950, 112, 198.

4. Albert, A., and Keating, F. R., Jr., Metabolic studies with $I^{\text {In }}$ labeled thyroid compounds. Comparison of the distribution and fate of radioactive d-1-thyroxine after oral and intravenous administration in the human. J. Clin. Endocrinol., 1949, 9, 1406.

5. Myant, N. B., and Pochin, E. E., The metabolism of radiothyroxine in man. Clin. Sc., 1950, 9, 421.

6. Riggs, D. S., Quantitative aspects of iodine metabolism in man. Pharmacol. Rev., 1952, 4, 284.

7. Werner, S. C., Quimby, E. H., and Schmidt, C., The use of tracer doses of radioactive iodine, $I^{2 m}$, in the study of normal and disordered thyroid function in man. J. Clin. Endocrinol., 1949, 9, 342.

8. Sterling, $K$., The turnover rate of serum albumin in man as measured by $I^{m}$-tagged albumin. J. Clin. Invest., 1951, 30, 1228.

9. Gordon, A. H., Gross, J., O'Connor, D., and PittRivers, R., Nature of the circulating thyroid hormone-plasma protein complex. Nature, 1952, 169, 19.

10. Hamolsky, M. W., Freedberg, A. S., Kurland, G. S., and Wolsky, L., The exchangeable thyroid hormonal pool. I. Its magnitude and rate of turnover in various thyroid states in man. J. Clin. Invest., 1953, 32, 453.

11. Berson, S. A., and Yalow, R. S., Personal communication.

12. Gross, J., and Pitt-Rivers, R., The identification of $3: 5: 3^{\prime}-1$-triiodothyronine in human plasma. Lancet, 1952, 1, 439.

13. Gross, J., and Pitt-Rivers, R., $3: 5: 3^{\prime}$-Triiodothyronine. I. Isolation from thyroid gland and synthesis. Biochem. J., 1953, 53, 645.

14. Gross, J., Pitt-Rivers, R., and Trotter, W. R., Effect of $3: 5: 3^{\prime}$-1-triiodothyronine in myxodema. Lancet, 1952, 1, 1044.

15. Rawson, R. W., Rall, J. E., Pearson, O. H., Robbins, J., Poppell, H. F., and West, C. D., 1-triiodothyronine versus 1-thyroxine, a comparison of their metabolic effects in human myxedema. Am. J. Med. Sc., 1953, n.s., 226, 405.

16. Asper, S. P., Jr., Selenkow, H. A., and Plamondon, C. A., A comparison of the metabolic activities of 3,5,3'-1-triiodothyronine and 1-thyroxine in myxedema. Bull. Johns Hopkins Hosp., 1953, 93, 164.

17. Lerman, J., The physiologic activity of 1-triiodothyronine. J. Clin. Endocrinol. \& Metab., 1953, 13, 1341.

18. Gross, J., and Leblond, C. P., Metabolites of thyroxine. Proc. Soc. Exper. Biol. \& Med., 1951, 76, 686.

19. Gross, J., Personal communication.

20. Deiss, W. P., Albright, E. C., and Larson, F. C., Comparison of in vitro serum protein binding of thyroxin and triiodothyromine. Proc. Soc. Exper. Biol. \& Med., 1953, 84, 513. 